\title{
A new ion imprinted polymer based on Ru(III)-thiobarbituric acid complex for solid phase extraction of ruthenium(III) prior to its determination by ETAAS
}

\author{
Elżbieta Zambrzycka • Beata Godlewska-Żyłkiewicz
}

Received: 11 November 2013 / Accepted: 28 January 2014 / Published online: 22 February 2014

(C) The Author(s) 2014. This article is published with open access at Springerlink.com

\begin{abstract}
A new ruthenium ion imprinted polymer was prepared from the $\mathrm{Ru}$ (III) 2-thiobarbituric acid complex (the template), methacrylic acid or acrylamide (the functional monomers), and ethylene glycol dimethacrylate (the cross-linking agent) using $2,2^{\prime}$-azobisisobutyronitrile as the radical initiator. The ion imprinted polymer was characterized and used as a selective sorbent for the solid phase extraction of $\mathrm{Ru}(\mathrm{III})$ ions. The effects of type of functional monomer, sample volume, solution $\mathrm{pH}$ and flow rate on the extraction efficiency were studied in the dynamic mode. $\mathrm{Ru}(\mathrm{III})$ ion was quantitatively retained on the sorbents in the $\mathrm{pH}$ range from 3.5 to 10 , and can be eluted with $4 \mathrm{~mol} \mathrm{~L}^{-1}$ aqueous ammonia. The affinity of $\mathrm{Ru}(\mathrm{III})$ for the ion imprinted polymer based on the acrylamide monomer is weaker than that for the polymer based on the methacrylic acid monomer, which therefore was used in interference studies and in analytical applications. Following extraction of $\mathrm{Ru}(\mathrm{III})$ ions with the imprint and their subsequent elution from the polymer with aqueous ammonia, $\mathrm{Ru}(\mathrm{III})$ was detected by electrothermal atomic absorption spectrometry with a detection limit of $0.21 \mathrm{ng} \mathrm{mL}^{-1}$. The method was successfully applied to the determination of trace amounts of $\mathrm{Ru}(\mathrm{III})$ in water, waste, road dust and platinum ore (CRM SARM 76) with a reproducibility (expressed as RSD) below $6.4 \%$.
\end{abstract}

Keywords Ruthenium $\cdot$ Separation $\cdot$ Preconcentration $\cdot$ Ion imprinted polymers $\cdot$ Environmental samples $\cdot$ Electrothermal atomic absorption spectrometry

\section{Introduction}

Ruthenium and its alloys are of commercial importance as they have widespread application in electronics, electrical and

E. Zambrzycka • B. Godlewska-Żyłkiewicz $(\bowtie)$

Institute of Chemistry, University of Bialystok, Hurtowa 1,

15-399 Bialystok, Poland

e-mail: bgodlew@uwb.edu.pl electrochemical industries. Above all, ruthenium and its complexes have been recognized as an efficient catalyst for a large number of reactions of commercial and environmental importance and exhibit classical catalyst characteristics in acidic as well as in alkaline media [1]. Ruthenium together with platinum is used as a bimetallic catalyst in electro-oxidation of methane in fuel cells [2]. Some ruthenium compounds possessing anticancer activity (e.g. NAMI-A, KP1019) are currently undergoing advanced preclinical testing [3]. Thus, the versatile use of ruthenium in different fields justifies the special attention in developing low cost, selective, sensitive and precise methods for its determination at trace levels.

Determination of ruthenium requires pretreatment of the sample ensuring quantitative conversion of ruthenium into soluble complexes, separation of the analyte from the interfering elements and preconcentration up to the level detected by the analytical technique employed. Solid phase extraction (SPE) based on anion-exchange resins is most often used for separation or preconcentration of ruthenium from the sample matrix [4]. Although the separation process using commercially available strong ion-exchangers is simple and efficient, these sorbents very often exhibit poor metal ion selectivity, as most of the platinum group metals are retained simultaneously. For the recovery of ruthenium from such sorbents either large volumes of concentrated mineral acids were used (e.g. $12 \mathrm{~mL}$ of $5 \mathrm{~mol} \mathrm{~L}^{-1} \mathrm{HNO}_{3}+5 \mathrm{~mol} \mathrm{~L}^{-1} \mathrm{HClO}_{4}$ [5], $10 \mathrm{~mL}$ of concentrated $\mathrm{HNO}_{3}$ [6], $100 \mathrm{~mL}$ of $12 \mathrm{~mol} \mathrm{~L}^{-1} \mathrm{HCl}$ [7]) or the resin was ashed and the residue was dissolved in acid before analysis [8]. Elution of ruthenium from polymers functionalized with chelating groups, such as polystyrenedivinylbenzene resin with thiosemicarbazide functional group [9], or polyacrylacylisothiourea chelating fibre [10] was also performed with aggressive reagents $\left(9 \mathrm{~mol} \mathrm{~L}^{-1} \mathrm{HCl}\right.$ or $\left.4 \mathrm{~mol} \mathrm{~L}^{-1} \mathrm{HCl}+1 \% \mathrm{CS}\left(\mathrm{NH}_{2}\right)_{2}\right)$.

The research in the synthesis of new sorption materials is striving to achieve of molecule specific sorbents. Molecularly imprinted polymers are prepared by creating a three- 
dimensional polymeric matrix around a template molecule. After the template is removed, complementary cavities with respect to shape and functional groups remains in the polymeric structure. The recognition is based on the morphology or stereochemistry of cavities. For separation of metal ions the technology of synthesis of ion imprinted polymers (IIP) has been developed [11]. In the ion imprinting process, the selectivity of polymer is based on the specificity of a ligand, on the coordination geometry and coordination number of the ions, on their charge and size [12]. The separation of ruthenium by means of IIP has been recently proposed by our research group [13-15]. The prepared materials based on imprinted complexes of ruthenium(III) with thiosemicarbazide and acetaldehyde thiosemicarbazone [15], benzaldehyde thiosemicarbazone [13] and allyl acetoacetate [14] are characterized by good selectivity and stability. On that basis the selective and accurate procedures for ruthenium determination in samples of natural waters, municipal wastes, grass and hair have been developed. However, the fact that sorption of the analyte on IIP occurred in neutral or alkaline solutions $(\mathrm{pH}$ from 6.5 to 10 ) precluded their potential application for very complex environmental samples, such as geological materials or road dust (due to co-precipitation of analyte with hydroxides of metals present in sample matrix).

To develop a method suitable for the determination of ruthenium in such samples a new ion imprinted polymer was designed and synthesized. A 2-thiobarbituric acid (TBA) (2-thioxodihydro-4,6(1H,5H)-pyrimidinedione), containing a pyrimidine ring with electro donor atoms $(\mathrm{N}$ and $\mathrm{S})$ and three mobile $\mathrm{H}$ atoms, was selected as a ligand complexing $\mathrm{Ru}(\mathrm{III})$ ion [16, 17]. In acidic solutions (pH 0.6-4) TBA forms a stable Ru(III)-TBA complex (1:2 molar ratio) through the coordination sulfur-metal bond [18]. The IIP was synthesized through bulk polymerization using $\mathrm{Ru}(\mathrm{III})$-TBA complex as a template molecule, methacrylic acid or acrylamide as a functional monomer and ethylene glycol dimethacrylate as a cross-linking agent. The particles of IIP polymers were employed in SPE procedure for the separation of ruthenium from complex environmental samples (river water, sewage, road dust and platinum ore) before its determination by electrothermal atomic absorption spectrometry (ETAAS).

\section{Experimental}

Instrumentation

A Solaar M6 (Thermo Electron Corporation, UK, www. thermoscientific.com) atomic absorption spectrometer, equipped with an electrothermal atomizer, a Zeeman background correction system, and a ruthenium hollow cathode lamp (10 mA) (Thermo Scientific, USA, www. thermoscientific.com) were used for the determination of ruthenium. The integrated absorbance signal of ruthenium was measured at $349.9 \mathrm{~nm}$ with a spectral bandpass of 0 . $2 \mathrm{~nm}$, using pyrolytically coated graphite tubes. The following optimized furnace heating program was used: drying at $110^{\circ} \mathrm{C}$ for $30 \mathrm{~s}$, ashing at $1,200^{\circ} \mathrm{C}$ for $20 \mathrm{~s}$, and atomization at $2,650^{\circ} \mathrm{C}$ for $3 \mathrm{~s}$.

The FT-IR absorption spectra $\left(4,000-500 \mathrm{~cm}^{-1}\right)$ were recorded with $\mathrm{KBr}$ pellets using a Thermo Nicolet Magna IR 550 Series II (Nicolet, Japan, www.thermoscientific.com). A Surface Area and Porosity Analyser Gemini VII 2390 (Micromeritics, USA, www.micromeritics.com) was used for the determination of surface area by BET method. Nitrogen sorption analysis was carried out on approximately $\sim 0.4 \mathrm{~g}$ portions of polymers degassed for $24 \mathrm{~h}$ at $80^{\circ} \mathrm{C}$.

An inoLab pH Level 1 (WTW, Germany, www.wtw.de) pH meter, equipped with a SenTix 21 electrode (WTW, Germany, www.wtw.de), was used for the $\mathrm{pH}$ measurements. A flow system used for the separation of ruthenium consisted of a peristaltic pump Minipuls 3 (Gilson, France, www.gilson.com), PTFE tubes with an i.d. of $0.8 \mathrm{~mm}$, and glassy adsorption columns with an i.d. of $3.4 \mathrm{~mm}$ containing PTFE frits. The digestion of samples was performed in an ETHOS PLUS (Milestone, Italy, www.milestonesrl.com) microwave system.

\section{Reagents and materials}

A ruthenium atomic spectroscopy standard solution in $\mathrm{HCl}$ (1 mg mL ${ }^{-1}$, Fluka, Switzerland, www.sigmaaldrich.com) was used. Sodium hydroxide (POCh, Poland, www.poch.com) solution $\left(1 \mathrm{~mol} \mathrm{~L}^{-1}\right)$ was used to adjust the $\mathrm{pH}$ of samples and standards. Acetic acid (80\%, POCh, Poland, www.poch.com) was used to remove interferents from columns. Ammonia (25\%, POCh, Poland, www.poch.com) and thiourea (puris p.a., Fluka, China, www.sigmaaldrich.com) were used as desorption agents. Nitric acid (69.5\%, Trace Select, Fluka, France, www. sigmaaldrich.com) and hydrochloric acid (37\%, fuming, Trace Select, Fluka, France, www.sigmaaldrich.com) were used for the digestion of samples.

Ruthenium(III) chloride hydrate (purum, $41 \%$ Ru, Fluka, UK, www.sigmaaldrich.com), 2-thiobarbituric acid (TBA, Merck, Germany) and ethanol (99.8 \%, POCh, Poland, www. poch.com) were used for the preparation of $\mathrm{Ru}(\mathrm{III})$ complexes. Ethylene glycol dimethacrylate (98\%, EGDMA, Sigma Aldrich, USA, www.sigmaaldrich.com), methacrylic acid (99 \%, MMA, Sigma Aldrich, USA, www.sigmaaldrich.com), acrylamide (99.9 \% pure, ACM, Bio-Rad Laboratories Headquarters, USA, www.bio-rad.com) and 2,2'-azobisisobutyronitrile (AIBN, Fluka, France, www.sigmaaldrich.com) were used for the synthesis of polymers. Methanol $(99.8 \%$, POCh, Poland, www.poch.com) was used as a porogen. Ethyl acetate (POCh, Poland, www.poch.com) was used to remove the excess of polymerization reagents. Certified reference material - platinum 
ore (SARM 76, MINTEK, www.mintek.co.za) from the Merensky Reef area, South Africa, was used for accuracy studies.

Solutions of palladium(II), rhodium(III) and iron(III) chlorides, cobalt(II) and nickel(II) nitrates (SCP Science, Canada, www.scpscience.com), and platinum as hexachloroplatinic(IV) acid (30\%, POCh, Poland, www.poch.com) were used to study the matrix interference. All solutions were prepared in deionized water obtained from a Milli-Q water purification system (Millipore, USA, www.millipore.com).

Synthesis of Ru(III)-2-thiobarbituric acid complex

The complex of $\mathrm{Ru}(\mathrm{III})-2$-thiobarbituric acid (Ru(III)-TBA) (the template) was prepared according to the procedure described in [18]. Ruthenium(III) chloride hydrate $(4.1 \mathrm{mg}$, $0.0198 \mathrm{mmol}$ ) was dissolved in $5.5 \mathrm{~mL}$ mixture of ethanol and concentrated $\mathrm{HCl}(1+1)$, next $1.6 \mathrm{~mL}$ of aqueous solution of TBA (7.1 mg, $0.0493 \mathrm{mmol}$ TBA) was added and the resulting solution was diluted with ethanol to volume of $13 \mathrm{~mL}$. The mixture was heated for $60 \mathrm{~min}$ on a water-bath at temp. $75^{\circ} \mathrm{C}$. The dark brown residue of the formed complex was dried in a vacuum evaporator. FT-IR $\left(\mathrm{KBr}, \mathrm{cm}^{-1}\right): 3,178$ $3,128\left(v_{\mathrm{N}-\mathrm{H}}\right), 1,714\left(v_{\mathrm{C}=\mathrm{O}}\right), 1,559-1,535\left(\delta_{\mathrm{N}-\mathrm{H}}, v_{\mathrm{C}=\mathrm{C}}, v_{\mathrm{C}=\mathrm{O}}\right.$, $\left.v_{\mathrm{C}=\mathrm{N}}\right), 1,420\left(\delta_{\mathrm{N}-\mathrm{H}}\right), 1,347\left(v_{\mathrm{C}=\mathrm{N}}, v_{\mathrm{C}=\mathrm{S}}\right), 1,298-1,273\left(v_{\mathrm{C}-\mathrm{N}}\right.$, $\left.v_{\mathrm{C}=\mathrm{S}}\right), 1,250\left(v_{\mathrm{C}=\mathrm{N}}, v_{\mathrm{C}-\mathrm{S}}\right), 933,801\left(\delta_{\mathrm{C}-\mathrm{H}}\right)$. The main IR spectra of TBA and Ru(III)-TBA complex in the solid state show similar bands. Small differences were observed in the absorption bands $\left(v_{\mathrm{N}-\mathrm{H}}\right),\left(v_{\mathrm{C}=\mathrm{S}}\right)$ and $\left(v_{\mathrm{C}-\mathrm{S}}\right)$. The absorption band $\left(v_{\mathrm{N}-\mathrm{H}}\right)$ of the ligand at $3,110 \mathrm{~cm}^{-1}$ was shifted to $3,178 \mathrm{~cm}^{-1}$ in $\mathrm{Ru}(\mathrm{III})$-TBA complex suggesting that the NH groups took part in the formation of a bond with $\mathrm{Ru}(\mathrm{III})$ ion. Moreover, the band present at $1,298 \mathrm{~cm}^{-1}$ in the TBA spectrum (assigned to the $\mathrm{C}=\mathrm{S}$ stretching vibrations) was considerably weakened and shifted to $1,282 \mathrm{~cm}^{-1}$ in the $\mathrm{Ru}(\mathrm{III})$ TBA complex spectrum, which indicates that the coordination of $\mathrm{Ru}(\mathrm{III})$ took place through the sulphur atom of the $\mathrm{C}=\mathrm{S}$ group.

Preparation of ruthenium(III) imprinted polymers and their characteristics

The $\mathrm{Ru}(\mathrm{III})$ imprinted polymers were prepared by bulk polymerization technique according to the scheme presented in Fig. 1. The complex of $\mathrm{Ru}(\mathrm{III})-\mathrm{TBA}$ containing $0.002 \mathrm{~g}$ $(0.0197 \mathrm{mmol})$ of $\mathrm{Ru}(\mathrm{III})$ was dissolved in $4 \mathrm{~mL}$ of methanol and transferred into glassy polymerization ampoules. Then, methacrylic acid (MMA) $(4.012 \mathrm{mmol})$ or acrylamide (ACM) (4.011 mmol), EGDMA (15.9 mmol) and AIBN (0.1 g) were added and the mixture was stirred until the solution was clear. The ampoules were purged with argon for $10 \mathrm{~min}$ to remove any dissolved oxygen, which could inhibit free radical polymerization. The reaction temperature was kept constant at
$55{ }^{\circ} \mathrm{C}$ for $24 \mathrm{~h}$. The resultant hard polymer monolith was crushed in a mortar and washed with ethyl acetate in order to remove the excess of reagents. The polymer was then dried, ground and sieved. The fraction of $100-150 \mu \mathrm{m}$ in diameter was used as a column filling. Control polymers (CP) were synthesized in a similar way, but in the absence of $\mathrm{Ru}(\mathrm{III})$ ions. The imprinted $\mathrm{Ru}(\mathrm{III})$ ions were leached from individual portions of the polymers $(0.4 \mathrm{~g})$ by passing a $100 \mathrm{~mL}$ solution of $6.0 \mathrm{~mol} \mathrm{~L}^{-1} \mathrm{HCl}$.

The IIP and respective CP have similar IR spectra indicating the similarity in the backbone structure. FT-IR of RuTBA-MAA $\left(\mathrm{KBr}, \mathrm{cm}^{-1}\right)$ : 3,565 $\left(v_{\mathrm{O}-\mathrm{H}}\right), 2,992\left(v_{\mathrm{C}-\mathrm{H}}\right), 1,732$ $\left(v_{\mathrm{C}=\mathrm{O}}\right), 1,256,1,147\left(v_{\mathrm{C}-\mathrm{O}}\right), 2,992,2,959,1,456,1,392$ and $754\left(v_{\mathrm{C}-\mathrm{H}}\right)$; FT-IR of Ru-TBA-ACM polymer $\left(\mathrm{KBr}, \mathrm{cm}^{-1}\right)$ : $3,448\left(v_{\mathrm{N}-\mathrm{H}}\right), 2,956\left(v_{\mathrm{C}-\mathrm{H}}\right), 1,729\left(v_{\mathrm{C}=\mathrm{O}}\right), 1,261,1,157\left(v_{\mathrm{C}}\right.$ $\left.{ }_{-\mathrm{O}}\right), 1,457,1,389$ and $754\left(v_{\mathrm{C}-\mathrm{H}}\right)$. The characteristic bands of the polymeric matrix of MMA-EGDMA at 2,992, 2,959, $1,456,1,392$ and $754 \mathrm{~cm}^{-1}$ corresponding to the $\mathrm{C}-\mathrm{H}$ stretching vibrations of the methylene groups $\left(v_{\mathrm{C}-\mathrm{H}}\right)$ and at $1,732 \mathrm{~cm}^{-1}$ corresponding to the $\mathrm{C}=\mathrm{O}$ stretching vibrations of the carbonyl group $\left(v_{\mathrm{C}=\mathrm{O}}\right)$ were observed in the spectra of IIP and CP polymer. The FT-IR spectrum of the polymeric matrix of ACM-EGDMA showed characteristic bands at $3,448 \mathrm{~cm}^{-1}$ corresponding to the $\mathrm{N}-\mathrm{H}$ stretching vibrations and at $1,729 \mathrm{~cm}^{-1}$ corresponding to the $\mathrm{C}=\mathrm{O}$ stretching vibrations of the amide group. The characteristic strong absorption bands of the polymeric matrix obscure the weak bands originating from the imprinted $\mathrm{Ru}(\mathrm{III})-\mathrm{TBA}$ complex.

The BET surface areas for the polymers prepared using methacrylic acid were $211.3 \mathrm{~m}^{2} \mathrm{~g}^{-1}$ for the $\mathrm{CP}$ and $232.9 \mathrm{~m}^{2} \mathrm{~g}^{-1}$ for the IIP. The BET surface areas for the polymers prepared using acrylamide were $121.3 \mathrm{~m}^{2} \mathrm{~g}^{-1}$ for the CP and $144.1 \mathrm{~m}^{2} \mathrm{~g}^{-1}$ for the IIP. Scanning electron microscopic images are presented in Fig. 2. The textural characteristics were examined at $2,000 \times$ magnification, revealing distinctive pattern on the imprinted surfaces, with more rough surface of the Ru-TBA-MAA polymer. The surface of both CP polymers displays the lack of comparable porous structure.

Pre-treatment and analysis of environmental samples

Tap water, road runoff and municipal sewage were spiked with $50 \mathrm{ng} \mathrm{mL}^{-1}$ of ruthenium. River water was spiked with 1 and $50 \mathrm{ng} \mathrm{mL}^{-1}$ of ruthenium. After an overnight equilibration, the samples were filtered through PVDF filters (Whatman, $0.45 \mu \mathrm{m}$ ) and adjusted to $\mathrm{pH} 4.1 \pm 0.1$ with diluted $\mathrm{NaOH}$. About $0.2 \mathrm{~g}$ of platinum ore (CRM SARM-76) and road dust collected from the main intersection located in the centre of Białystok (Poland) were weighed into Teflon vessels and leached with $8 \mathrm{~mL}$ of aqua regia using a microwave digestion system according to the procedure described in [19]. The $2 \mathrm{~mL}$ portions of solutions were transferred to quartz 
Fig. 1 Schematic illustration of the imprinting process for preparation of the ruthenium imprinted polymer using methacrylic acid as functional monomer<smiles>C=C(C)C(=O)O</smiles><smiles>C=C(C)C(=O)OCCOC(=O)C(=C)C</smiles>

bulk polymerization: porogen: methanol $55^{\circ} \mathrm{C}, 24 \mathrm{~h}$ initiator: AIBN

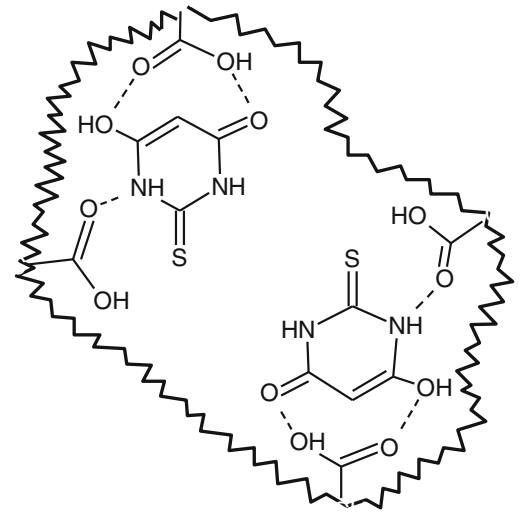

leaching of $\mathrm{Ru}$ $6.0 \mathrm{~mol} \mathrm{~L}^{-1} \mathrm{HCl}$

rebinding of $\mathrm{Ru}$

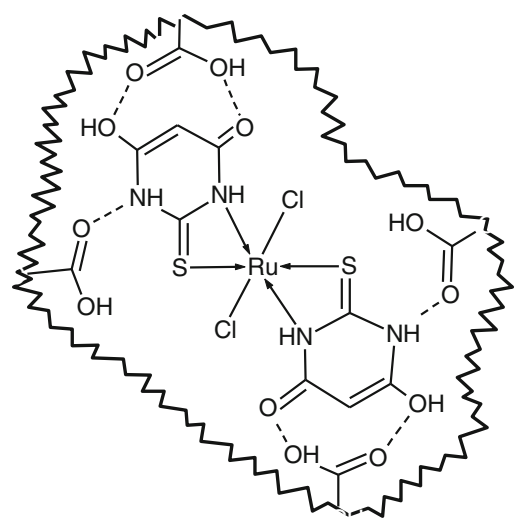

crucibles, evaporated with $2 \mathrm{~mL}$ of concentrated $\mathrm{HCl}$ near to dryness three times and diluted with water. The $\mathrm{pH}$ of such pretreated samples of road dust and platinum ore was adjusted to $\mathrm{pH} 3.5$ using diluted $\mathrm{NaOH}$ directly before being loaded onto the column.

Glassy columns packed with $0.1 \mathrm{~g}$ of IIP were preconditioned by passing $4.5 \mathrm{~mL}$ of water. The samples (2$100 \mathrm{~mL}$ ) adjusted to desired $\mathrm{pH}$ were passed through the column at a flow rate of $1.2 \mathrm{~mL} \mathrm{~min}^{-1}$. The elution of $\mathrm{Ru}(\mathrm{III})$ ions was accomplished by passing $2 \mathrm{~mL}$ of $4.0 \mathrm{~mol} \mathrm{~L}^{-1}$ ammonia solution through the column at a flow rate of $0.4 \mathrm{~mL} \mathrm{~min}^{-1}$. For the analysis of road dust and platinum ore the column was rinsed with $4 \mathrm{~mL}$ of $0.05 \mathrm{~mol} \mathrm{~L}^{-1}$
$\mathrm{CH}_{3} \mathrm{COOH}$ before elution step. The content of ruthenium in all solutions was analyzed by ETAAS.

\section{Results and discussion}

Optimization of ruthenium separation conditions

Our previous studies concerning the size of columns have shown that using longer and narrower columns resulted in improved efficiency of the retention of the analyte (up to $20 \%$ ) and better reproducibility of the separation process [13]. Therefore, in this work the glassy columns $(110 \mathrm{~mm} \times$
Fig. 2 SEM images of the surface of the IIP and CP polymers $(2,000$-fold magnification) prepared using different functional monomers: a methacrylic acid, b acrylamide
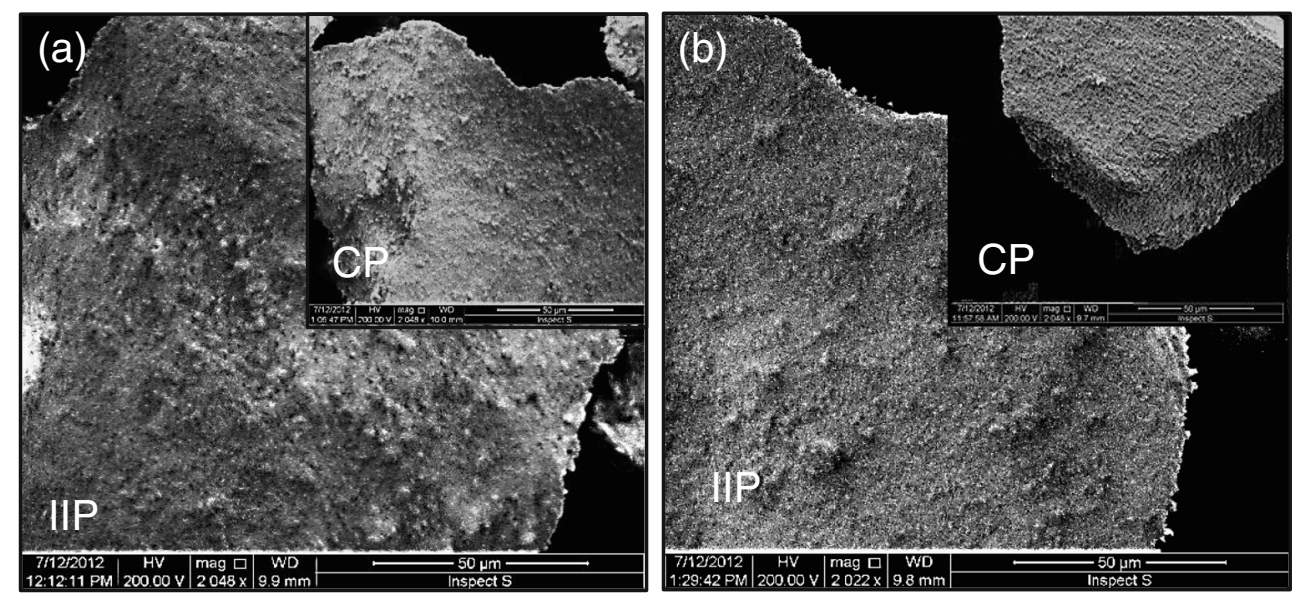
$3.4 \mathrm{~mm}$ i.d) filled with $0.1 \mathrm{~g}$ of polymer were used. The columns were preconditioned with water.

The effects of the sample $\mathrm{pH}$ and the rate of passing the sample solution through the columns, the kind of eluent, its flow rate and volume on the retention of $\mathrm{Ru}(\mathrm{III})$ ions were studied simultaneously on both IIP polymers. The retention efficiency was calculated as a ratio of the mass of Ru retained on the column to the initial mass of $\mathrm{Ru}$ loaded onto the column. It was observed that the efficiency of retention of analyte on Ru-TBA-MAA polymer was low (8-30\%) in acidic solutions $(1<\mathrm{pH} \leq 3)$, rapidly increased to $80 \%$ in solutions of $\mathrm{pH} 3.5$, and exceeded $90 \%$ in solutions in the $\mathrm{pH}$ range from 4 to 10 . The behavior of Ru-TBA-ACM polymer was very similar, however the efficiencies of ruthenium retention were lower by $3-10 \%$ in whole studied $\mathrm{pH}$ range. In order to prevent precipitation of hydroxides of other metals present in the matrix of analyzed samples the sample $\mathrm{pH}$ was adjusted to $\mathrm{pH} 4.1 \pm 0.1$ in further studies. The efficiency of retention of $\mathrm{Ru}(\mathrm{III})$ on respective $\mathrm{CP}$ at the $\mathrm{pH}$ range of $3.5-5$ was lower by $12-15 \%$. The flow rate of $\mathrm{Ru}(\mathrm{III})$ solutions in the range from 0.2 to $1.5 \mathrm{~mL} \mathrm{~min}^{-1}$ practically does not affect the efficiency of sorption on IIP (91.8-90.5\%). Thus, the flow rate of $1.2 \mathrm{ml} \mathrm{L}^{-1}$ was chosen for subsequent experiments. The similar flow rate $\left(1.5 \mathrm{~mL} \mathrm{~min}^{-1}\right)$ was used in the case of polymer based on $\mathrm{Ru}(\mathrm{III})$-thiosemicarbazide com-

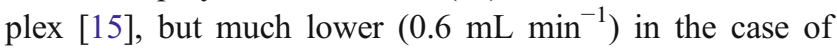
polymer with imprinted $\mathrm{Ru}(\mathrm{III})$-allyl acetoacetate complex [14]. This indicates that the Ru-TBA-MAA and Ru-TBAACM polymers are characterized by fast kinetics of sorption. Our previous studies [13-15] demonstrated that quantitative elution of $\mathrm{Ru}$ (III) from IIP could be obtained using acidic solutions of thiourea. Thus, solutions of different concentrations of thiourea and $\mathrm{HCl}\left(0.1-0.9 \mathrm{~mol} \mathrm{~L}^{-1}\right.$ of thiourea and $0.1-0.5 \mathrm{~mol} \mathrm{~L}^{-1}$ of $\left.\mathrm{HCl}\right)$ were tested as stripping agents. The efficiencies of elution of analyte, calculated as a ratio of the mass of Ru eluted from the column by a stripping agent to the mass of $\mathrm{Ru}$ retained on the column, with these eluents were not satisfactory $(\leq 75 \%)$, thus the ammonia solutions $\left(0.2-5 \mathrm{~mol} \mathrm{~L}^{-1}\right)$ were tested afterwards. The ruthenium elution from Ru-TBA-MAA polymer was rising with increasing concentrations of ammonia solutions (up to $87 \%$ for $4 \mathrm{~mol} \mathrm{~L}^{-1} \mathrm{NH}_{3} \cdot \mathrm{H}_{2} \mathrm{O}$ ). The effect of eluent flow rate on the efficiency of elution was studied in the range of $0.2-$ $0.8 \mathrm{~mL} \mathrm{~min}^{-1}$. The highest efficiency of elution (87-94\%) was obtained at the flow rates of $0.2-0.4 \mathrm{~mL} \mathrm{~min}^{-1}$ with 2-3 $\mathrm{mL}$ of $\mathrm{NH}_{3} \cdot \mathrm{H}_{2} \mathrm{O}$. The efficiencies of ruthenium elution from the Ru-TBA-ACM polymer were higher by 3-6\% than from the Ru-TBA-MAA polymer.

It is worth stressing that the signal of ruthenium standard in 1-5 mol L $\mathrm{NH}_{3} \cdot \mathrm{H}_{2} \mathrm{O}$ solutions was about $40 \%$ higher in comparison to its signal in water, but $20 \%$ lower than in diluted solutions of $\mathrm{HCl}$ [15]. The other positive effect of the chosen eluent could be that ammonia complexes of some interfering metals, e.g. nickel and copper decompose in a graphite furnace at $400{ }^{\circ} \mathrm{C}[20]$.

For removal of interferents rinsing of column with a solvent solution before elution step is often recommended. Rinsing the IIP column with $4 \mathrm{~mL}$ of water or $0.05 \mathrm{~mol} \mathrm{~L}^{-1}$ acetic acid caused the removal of 6.2 or $8.5 \%$ of retained $\mathrm{Ru}(\mathrm{III})$, respectively. More than $24 \%$ of the analyte was removed in this step from the CP.

Under optimized conditions the efficiency of the retention of ruthenium (100 ng, $n=3$ ) on the Ru-TBA-MAA polymer was $93.4 \pm 1.5 \%$, whereas the elution efficiency was $89.7 \pm$ $0.7 \%$. The recovery of the analyte from the IIP, calculated as a ratio of the mass of Ru eluted from the column to the initial mass of Ru loaded onto the column, was $83.8 \pm 1.8 \%$, while from the $\mathrm{CP}$ was $45.1 \pm 5.9 \%$. The efficiency of the retention of ruthenium on the Ru-TBA-ACM polymer was $89.0 \pm$ $0.7 \%$, whereas the efficiency of elution was $93.9 \pm 2.9 \%$, and the recovery was $83.6 \pm 2.8 \%$. The recovery of ruthenium from the CP was $30.2 \pm 3.1 \%$ (Fig. 3a). Reproducibility of the results for 15 successive sorption-desorption cycles was good $(\mathrm{RSD}<7 \%$ ), allowing multiple use of the sorbent as column filling in flow procedures.

The breakthrough capacity of the polymer was determined according to the procedure described in [13]. The capacity of the polymer prepared with methacrylic acid was $36.6 \mu \mathrm{g} \mathrm{g}^{-1}$

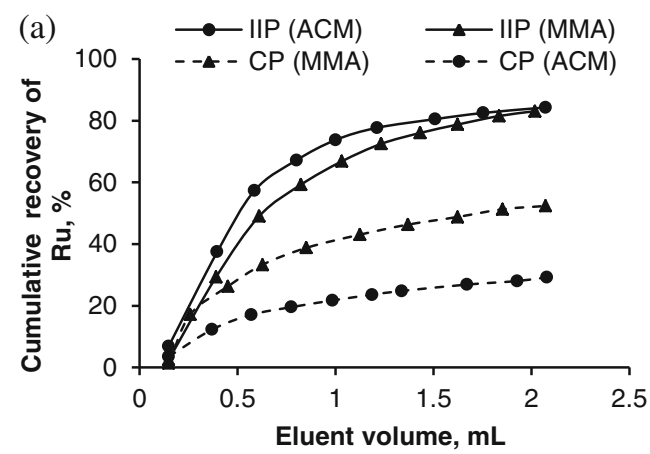

(b)

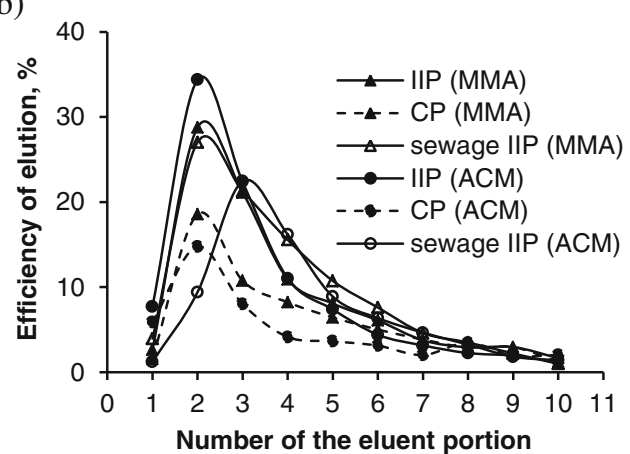

Fig. 3 Elution of $\mathrm{Ru}(\mathrm{III})$ from IIP and $\mathrm{CP}$ with $0.2 \mathrm{~mL}$ portions of $4 \mathrm{~mol} \mathrm{~L}{ }^{-1} \mathrm{NH}_{3} \cdot \mathrm{H}_{2} \mathrm{O}$ (eluent flow rate $0.4 \mathrm{~mL} \mathrm{~min}^{-1}$ ): a cumulative recovery of $\mathrm{Ru}(\mathrm{III})$ from standard solution (MMA - methacrylic acid, ACM - acrylamide), $\mathbf{b}$ elution profiles of Ru(III) from standard solution and sewage 
for the IIP and $25.1 \mu \mathrm{g} \mathrm{g}^{-1}$ for the CP. The capacity of this IIP is about 16 times larger than the capacity of the $\mathrm{Ru}(\mathrm{III})$-allyl acetoacetate imprinted polymer [14]. The capacity of the polymer prepared with acrylamide was $34.5 \mathrm{\mu g} \mathrm{g}^{-1}$ for the IIP and $21.0 \mu \mathrm{g} \mathrm{g}^{-1}$ for the CP. The average durability of the column filled with IIP was around 300 analytical sorption/ desorption cycles for the Ru-TBA-MMA polymer and $250 \mathrm{cy}$ cles for the Ru-TBA-ACM polymer.

These results indicate minor influence of the type of functional monomer on the analytical performance of polymer, however it seems that the affinity of ruthenium for the RuTBA-MMA polymer is slightly higher. The profiles of elution shown in Fig. $3 b$ confirm that $\mathrm{Ru}(\mathrm{III})$ is more specifically bound to the IIP than to the $\mathrm{CP}$, and that there is a slight difference in the affinity of both polymers for Ru(III). Owing to better characteristics of the Ru-TBA-MMA polymer, this polymer was used for interference studies and analytical applications.

\section{Study of interference effects}

The imprinting effect and the ion-recognizing behavior of imprinted materials are reflected by polymer selectivity in the presence of competing ions. The selection of metal ions for this study was based on the similarity of chemical properties of other metals to the analyte, the similarity of an ionic radius, and a degree of interference effect in the determination of Ru by ETAAS technique. The most serious interference in the ruthenium determination is caused by the presence of $\mathrm{Co}(\mathrm{II}), \mathrm{Ni}(\mathrm{II})$, and $\mathrm{Pt}(\mathrm{IV}), \mathrm{Pd}(\mathrm{II})$ and $\mathrm{Rh}$ (III) ions [15].

The distribution ratios $\left(D, \mathrm{~mL} \mathrm{~g}^{-1}\right)$, selectivity coefficients $(\alpha)$ and relative selectivity coefficients $\left(\alpha_{r}\right)$ of $\mathrm{Ru}(\mathrm{III})$, with respect to $\mathrm{Pd}(\mathrm{II}), \mathrm{Pt}(\mathrm{IV}), \mathrm{Rh}(\mathrm{III}), \mathrm{Co}(\mathrm{II}), \mathrm{Ni}(\mathrm{II})$, and $\mathrm{Fe}(\mathrm{III})$ ions determined for the IIP were calculated in a dynamic system from the equations described in [15]. A comparison of $D$ values for $\mathrm{Ru}(\mathrm{III})$ ions on the IIP and CP polymers shows that higher distribution ratios were achieved on the imprinted polymer (Table 1). These values are higher for $\mathrm{Ru}$ (III) than for other studied ions with the exception of $\mathrm{Ni}(\mathrm{II})$. The high $D$ values obtained for $\mathrm{Ni}$ (II) ions both on IIP and $\mathrm{CP}$ suggest nonspecific sorption of these ions to the polymeric network. The relative selectivity coefficients, which express the selectivity of the imprinted polymers in comparison to the control polymer, are greater than 2.2. The selectivity of the polymer studied in this work is much better than the selectivity obtained for polymers based on imprinted complexes of $\mathrm{Ru}$ (III) with thiosemicarbazide [15], but slightly worse than that obtained for polymers with imprinted Ru(III)-benzaldehyde thiosemicarbazone complex [13].

The effect of interfering ions on the retention of ruthenium and its elution was also assessed. The efficiency of retention of $\mathrm{Ru}(\mathrm{III})$ on the IIP from a solution containing up to $1 \mu \mathrm{g}$ of other metal ions was slightly affected by the presence of
Table 1 Selectivity parameters of IIP and CP polymers with methacrylic acid for $\mathrm{Ru}(\mathrm{III})$ ions against competitive sorption of other metal ions ( $2 \mathrm{~mL}$ of sample: $100 \mathrm{ng} \mathrm{Ru}+100 \mathrm{ng}$ of other ion, $\mathrm{pH} 4.1$, flow rate: $1.2 \mathrm{~mL} \mathrm{~min}^{-1}, \mathrm{n}=3$ )

\begin{tabular}{|c|c|c|c|c|c|}
\hline \multirow[t]{2}{*}{ Metal ion } & \multicolumn{2}{|c|}{ Distribution ratio (D), $\mathrm{mL} \mathrm{g}^{-1}$} & \multicolumn{2}{|c|}{ Selectivity coefficient, $\alpha$} & \multirow[t]{2}{*}{$\alpha_{\mathrm{r}}$} \\
\hline & $\mathrm{CP}$ & IIP & $\mathrm{CP}$ & IIP & \\
\hline $\mathrm{Ru}(\mathrm{III})$ & 60.9 & 283 & - & - & - \\
\hline $\mathrm{Pt}(\mathrm{IV})$ & 2.36 & 1.97 & 25.8 & 144 & 5.6 \\
\hline $\mathrm{Pd}(\mathrm{II})$ & 186 & 99.6 & 0.30 & 2.80 & 9.5 \\
\hline $\mathrm{Rh}(\mathrm{III})$ & 1.80 & 1.44 & 33.8 & 196 & 5.8 \\
\hline $\mathrm{Fe}(\mathrm{III})$ & 53.9 & 103 & 1.13 & 2.70 & 2.2 \\
\hline $\mathrm{Co}(\mathrm{II})$ & 157 & 102 & 0.39 & 2.80 & 6.9 \\
\hline $\mathrm{Ni}(\mathrm{II})$ & 439 & 466 & 0.14 & 0.61 & 4.3 \\
\hline
\end{tabular}

Pt(IV) (Table 2). The efficiency of elution of Ru(III) from the sorbent and in consequence its recovery was influenced only by the presence of $\mathrm{Fe}(\mathrm{III})$ ions. At solutions of $\mathrm{pH}>4$ higher amounts of $\mathrm{Fe}(\mathrm{III})$ ions may precipitate in the form of $\mathrm{Fe}(\mathrm{OH})_{3}$. During the course of elution with ammonia the ammonia complexes of $\mathrm{Ru}(\mathrm{III})$ (e.g. $\left.\left[\mathrm{Ru}\left(\mathrm{NH}_{3}\right)_{3}\right]^{3+}\right)$ may possibly be sorbed on the surface of formed iron hydroxide precipitate and slowly undergo decomposition as it was

Table 2 Effect of the presence of competitive ions on the separation of $\mathrm{Ru}(\mathrm{III})$ ions $(100 \mathrm{ng})$ on IIP with methacrylic acid $(2 \mathrm{~mL}$ of sample: $\mathrm{pH} 4.1$, mean value \pm SD for $n=3$ )

\begin{tabular}{lllll}
\hline Metal ion & $\mathrm{C}_{\text {int }} / \mathrm{C}_{\mathrm{Ru}}$ & $\begin{array}{l}\text { Ru retention } \\
\text { efficiency, } \%\end{array}$ & $\begin{array}{l}\text { Ru elution } \\
\text { efficiency, } \%\end{array}$ & Recovery, $\%$ \\
\hline $\mathrm{Ru}(\mathrm{III})$ & - & $93.4 \pm 1.5$ & $89.7 \pm 0.7$ & $83.8 \pm 1.6$ \\
$\mathrm{Pd}(\mathrm{II})$ & 1 & $91.2 \pm 1.3$ & $91.6 \pm 2.1$ & $83.6 \pm 2.1$ \\
& 10 & $86.9 \pm 3.2$ & $91.3 \pm 2.3$ & $79.3 \pm 4.8$ \\
$\mathrm{Pt}(\mathrm{IV})$ & 1 & $87.8 \pm 2.0$ & $91.2 \pm 0.9$ & $80.1 \pm 1.3$ \\
& 5 & $91.5 \pm 2.2$ & $91.3 \pm 2.3$ & $83.6 \pm 4.1$ \\
& 10 & $74.7 \pm 3.2$ & $94.8 \pm 1.9$ & $72.7 \pm 1.3$ \\
$\mathrm{Rh}(\mathrm{III})$ & 1 & $92.7 \pm 3.5$ & $89.9 \pm 1.4$ & $83.3 \pm 2.1$ \\
& 10 & $83.2 \pm 1.9$ & $91.4 \pm 3.0$ & $76.0 \pm 3.3$ \\
$\mathrm{Co}(\mathrm{II})$ & 1 & $94.5 \pm 2.9$ & $90.9 \pm 2.9$ & $85.9 \pm 1.0$ \\
& 10 & $93.1 \pm 3.7$ & $94.3 \pm 1.7$ & $87.6 \pm 3.0$ \\
$\mathrm{Ni}(\mathrm{II})$ & 1 & $96.7 \pm 4.2$ & $91.7 \pm 3.9$ & $88.7 \pm 6.4$ \\
& 10 & $83.5 \pm 1.8$ & $98.5 \pm 4.7$ & $82.2 \pm 2.3$ \\
$\mathrm{Fe}(\mathrm{III})$ & 1 & $96.6 \pm 1.8$ & $84.6 \pm 1.9$ & $81.8 \pm 2.8$ \\
& 10 & $97.7 \pm 0.4$ & $48.9 \pm 4.6$ & $47.8 \pm 4.5$ \\
& 10 & $97.8 \pm 2.1$ & $68.3 \pm 1.9$ & $66.8 \pm 1.5^{\mathrm{a}}$ \\
& 10 & $95.2 \pm 1.1$ & $77.6 \pm 6.6$ & $76.9 \pm 0.6^{\mathrm{b}}$ \\
& 10 & $94.4 \pm 0.8$ & $79.8 \pm 2.4$ & $75.4 \pm 2.8^{\mathrm{c}}$ \\
\hline & & &
\end{tabular}

\footnotetext{
a Column clean-up with $4 \mathrm{~mL}$ of $0.05 \mathrm{~mol} \mathrm{~L}^{-1} \mathrm{CH}_{3} \mathrm{COOH}$,

b Sample pH 3.5,

c Sample pH 3.5 and column clean-up with $4 \mathrm{~mL}$ of $0.05 \mathrm{~mol} \mathrm{~L}^{-1}$ $\mathrm{CH}_{3} \mathrm{COOH}$.
} 


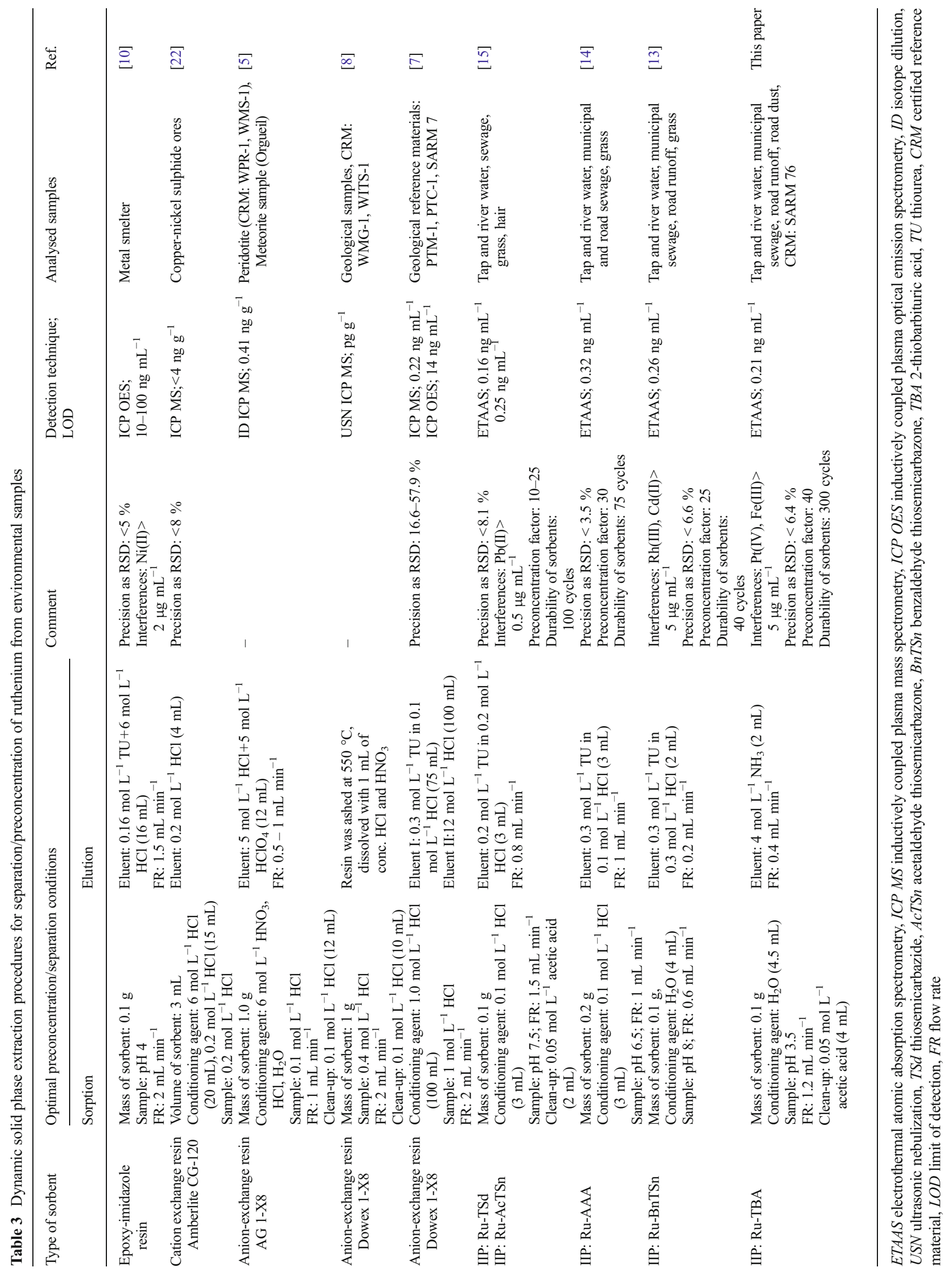


Table 4 Recovery of Ru(III) from various samples after its separation on IIP with methacrylic acid ( $2 \mathrm{~mL}$ of sample: $\mathrm{pH} 4.1$, mean value $\pm \mathrm{SD}, n=3$ )

\begin{tabular}{lllll}
\hline & $\mathrm{V}, \mathrm{mL}$ & $\mathrm{C}_{\mathrm{Ru}}, \mathrm{ng} \mathrm{mL}^{-1}$ & Ru added, ng & Recovery,\% \\
\hline MQ water & 2 & 50 & 100 & $98.7 \pm 2.8$ \\
River water & 10 & 1 & 10 & $97.1 \pm 1.7$ \\
& 20 & 1 & 20 & $95.7 \pm 3.4$ \\
& 60 & 1 & 60 & $93.1 \pm 0.7$ \\
& 80 & 1 & 80 & $89.8 \pm 1.3$ \\
& 100 & 1 & 100 & $80.9 \pm 4.9$ \\
Tap water & 2 & 50 & 100 & $97.1 \pm 4.1$ \\
Municipal sewage & 2 & 50 & 100 & $99.7 \pm 2.2$ \\
Road runoff & 2 & 50 & 100 & $98.4 \pm 2.1$ \\
Road dust & 6 & 16.7 & 100 & $94.5 \pm 2.8^{\mathrm{a}}$ \\
CRM SARM 76 & 2 & - & 100 & $90.0 \pm 3.3^{\mathrm{b}}$ \\
\hline
\end{tabular}

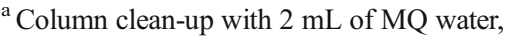

${ }^{\mathrm{b}}$ Sample $\mathrm{pH} 3.5$, column clean-up with $4 \mathrm{~mL}$ of $0.05 \mathrm{~mol} \mathrm{~L}^{-1}$ $\mathrm{CH}_{3} \mathrm{COOH}$,

${ }^{\mathrm{c}}$ Against the reference value $\left(0.49 \pm 0.023 \mu \mathrm{g} \mathrm{g}^{-1}\right)$

observed for other platinum group metals [20]. In order to remove Fe(III) ions from the column, the sorbent was cleanedup with $4 \mathrm{~mL}$ of $0.05 \mathrm{~mol} \mathrm{~L}^{-1}$ acetic acid before elution of the analyte was performed. During the clean-up a small part of the analyte $(8.5 \%)$ was removed. As a consequence the recovery of analyte in the presence of 10 -fold excess of Fe(III) was lower by $17 \%$ when compared to the recovery obtained for a standard solution. Better results were obtained when the sample $\mathrm{pH}$ was adjusted to 3.5 , which prevented the formation of $\mathrm{Fe}(\mathrm{OH})_{3}$ precipitate [21]. The recovery calculated from the calibration graph prepared under the same conditions was lower only by $7 \%$. The extra clean-up of the column with $0.05 \mathrm{~mol} \mathrm{~L}^{-1}$ acetic acid didn't affect the analyte recovery. These results confirm that the IIP can be used as a solid sorbent for separation of trace amounts of $\mathrm{Ru}(\mathrm{III})$ from other ions.

Analysis of environmental samples

For the determination of ruthenium by ETAAS the calibration graph technique was used. The standard ruthenium solutions were submitted to the separation procedure on IIP using $2 \mathrm{~mL}$ of the eluent solution. The calibration graph was linear up to $16 \mathrm{ng} \mathrm{mL} \mathrm{L}^{-1}$ of Ru. The limit of detection of Ru (calculated as $\mathrm{LOD}=$ blank $+3 \mathrm{SD}_{\text {blank }}$ according to IUPAC recommendation) was $0.21 \mathrm{ng} \mathrm{mL}^{-1}$ for $10 \mathrm{~mL}$ sample, while the limit of quantification $\left(\mathrm{LOQ}=\right.$ blank $\left.+10 \mathrm{SD}_{\text {blank }}\right)$ was $0.77 \mathrm{ng} \mathrm{mL}^{-1}$. The limit of detection is lower than that obtained by means of ion-exchange resins and inductively coupled plasma optical emission spectrometry $[7,10]$ or inductively coupled plasma mass spectrometry $[5,7,22]$ (Table 3 ). The enhancement factor, defined as the ratio of the slope of the calibration graphs before and after the preconcentration process, was 3.3.

The developed method was applied for separation/ preconcentration of $\mathrm{Ru}$ from river and tap water, waste (municipal sewage, road runoff) and road dust spiked with analyte. Since ruthenium belongs to metals characterised by a slow rate of ligand exchange, the samples (spiked with 10 $100 \mathrm{ng}$ of $\mathrm{Ru}$ ) were left overnight to reach equilibrium. The recovery of analyte from river water, tap water and municipal sewage was in the range of $97.1-99.7 \%$. The reproducibility of results expressed as RSD was in the range of 1.1-4.1\% (Table 4). The profile of elution of ruthenium present in municipal sewage from the IIP (Fig. 3b) confirms a proper selectivity of the IIP. However, the recovery of ruthenium from road runoff was too high indicating the occurrence of matrix interferences. Rinsing of a column with $2 \mathrm{~mL}$ of MQ water efficiently removed excess of matrix from the sorbent (Table 4).

Slightly modified procedure (sample $\mathrm{pH}$ adjusted to 3.5 and column clean-up with $0.05 \mathrm{~mol} \mathrm{~L}^{-1} \mathrm{CH}_{3} \mathrm{COOH}$ ) was used for the determination of $\mathrm{Ru}$ in road dust and platinum ore (CRM). Because the content of Ru in road dust was below the limit of detection of the method, the known amount of analyte was added to a mineralized sample, then the sample underwent the pretreatment procedure. The recovery of Ru from road dust was $90.0 \pm 3.3 \%$. The good accuracy of the method was confirmed by analysis of certified reference material of platinum ore (SARM 76) (Table 4). The signals of ruthenium registered directly for the solution of digested CRM sample and after the separation procedure (not shown) reveal efficient elimination of matrix interferences on the used IIP sorbent.

The ability of the prepared polymers to preconcentrate trace amounts of $\mathrm{Ru}(\mathrm{IIII})$ ions $\left(1 \mathrm{ng} \mathrm{mL}^{-1}\right)$ from large volumes of river water $(10-100 \mathrm{~mL})$ was also tested. The results confirmed that the procedure may be applied to the separation of trace amounts of $\mathrm{Ru}(\mathrm{III})$ from volumes up to $80 \mathrm{~mL}$ (Table 4).

\section{Conclusions}

New selective sorbents for the separation of $\mathrm{Ru}(\mathrm{III})$ by the SPE technique were prepared by an ion imprinting technique using complex of $\mathrm{Ru}$ (III) with 2-thiobarbituric acid (template), and methacrylic acid and acrylamide as functional monomers. It was found that the type of functional monomer only slightly affected the sorption properties of the sorbent. However, the affinity of $\mathrm{Ru}$ (III) for the Ru-TBA-ACM polymer was to some extent weaker than for the Ru-TBA-MMA polymer. The RuTBA-ACM polymer was characterised also by a lower surface area, sorption capacity and shorter durability. Thus, the RuTBA-MMA was used for interference studies and analytical 
application. This IIP is characterized by greater selectivity and adsorption capacity in comparison with $\mathrm{CP}$. The developed SPE method can be applied in a wide range of sample $\mathrm{pH}$ (3.5-10), which promotes the analysis of various types of samples. Acidic sample $\mathrm{pH}$ allows the selective separation of $\mathrm{Ru}$ from constituents of digested environmental samples, whereas neutral $\mathrm{pH}$ can be an advantage during separation of analytes from natural waters and wastes. The procedure of ruthenium separation on IIP from interfering matrix is shorter, more universal and selective in comparison to others (Table 3 ). The developed method is suitable for determination of trace amounts of ruthenium in complex environmental samples.

Acknowledgments The authors thank Dr. Agnieszka Z. Wilczewska (University of Bialystok, Institute of Chemistry, Poland) for the surface area and porosity measurements. The Surface Area and Porosity Analyser was funded by the EU, as part of the Operational Programme Development of Eastern Poland 2007-2013, project: POPW.01.03.00-20-034/09-00.

Open Access This article is distributed under the terms of the Creative Commons Attribution License which permits any use, distribution, and reproduction in any medium, provided the original author(s) and the source are credited.

\section{References}

1. Over H (2012) Surface chemistry of ruthenium dioxide in heterogeneous catalysis and electrocatalysis: from fundamental to applied research. Chem Rev 112:3356-3426

2. Bagotsky VS (2009) Fuel cells. Problems and solutions. Wiley, Hoboken

3. Bergamo A, Gaiddon C, Schellens JHM, Beijnen JH, Sava G (2012) Approaching tumour therapy beyond platinum drugs: status of the art and perspectives of ruthenium drug candidates. J Inorg Biochem 106: 90-99

4. Balcerzak M (2002) Analytical methods for the determination of ruthenium: the state of art. Crit Rev Anal Chem 32:181-226

5. Yi YV, Masuda A (1996) Simultaneous determination of ruthenium, palladium, iridium, and platinum at ultratrace levels by isotope dilution inductively coupled plasma mass spectrometry in geological samples. Anal Chem 68:1444-1450

6. Müller M, Heumann KG (2000) Isotope dilution inductively coupled plasma quadrupole mass spectrometry in connection with a chromatographic separation for ultratrace determinations of platinum group elements (Pt, Pd, Ru, Ir) in environmental samples. Fresenius J Anal Chem 368:109-115

7. Jarvis I, Totland MM, Jarvis KE (1997) Assessment of Dowex 1-X8based anion-exchange procedures for the separation and determination of ruthenium, palladium, iridium, platinum and gold in geological samples by inductively coupled plasma mass spectrometry. Analyst 122:19-26
8. Dai X, Koeberl C, Fröschl H (2001) Determination of platinum group elements in impact breccias using neutron activation analysis and ultrasonic nebulization inductively coupled plasma mass spectrometry after anion exchange preconcentration. Anal Chim Acta 436:7985

9. Siddhanta S, Das HR (1985) Separation and concentration of some platinum metal ions with a new chelating resin containing thiosemicarbazide as functional group. Talanta 32: $457-460$

10. Chang X, Su Z, Zhan G, Luo X, Gao W (1994) Synthesis and efficiency of a polyacrylacylisothiourea chelating fibre for the preconcentration and separation of trace amounts of gold, palladium and ruthenium from solution samples. Analyst 119:1445-1449

11. Branger C, Meouche W, Margaillan A (2013) Recent advances on ion-imprinted polymers. React Funct Polym 73:859-875

12. Mafu LD, Msagati TAM, Mamba BB (2013) Ion-imprinted polymers for environmental monitoring of inorganic pollutants: synthesis, characterization, and applications. Environ Sci Pollut Res 20: 790-802

13. Zambrzycka E, Kiedysz U, Wilczewska AZ, Leśniewska B, Godlewska-Żyłkiewicz B (2013) Novel ion imprinted polymer as a highly selective sorbent for separation of ruthenium ions from environmental samples. Anal Methods 5:3096-3105

14. Godlewska-Żyłkiewicz B, Zambrzycka E, Leśniewska B, Wilczewska A (2012) Separation of ruthenium from environmental samples on ion imprinted polymers based on imprinted $\mathrm{Ru}(\mathrm{III})$ allylacetate complex. Talanta 89:352-359

15. Zambrzycka E, Roszko D, Leśniewska B, Wilczewska A, Godlewska-Żyłkiewicz B (2011) Studies of ion-imprinted polymers for solid-phase extraction of ruthenium from environmental samples before its determination by electrothermal atomic absorption spectrometry. Spectrochim Acta B 66:508-516

16. Refat MS, El-Korashy SA, Ahmed AS (2008) A convenient method for the preparation of barbituric and thiobarbituric acid transition metal complexes. Spectrochim Acta A 71:1084-1094

17. Mendez E, Cerda MF, Gancheff JS, Torres J, Kremer C, Castiglioni J, Kieninger M, Ventura ON (2007) Tautomeric forms of 2-thiobarbituric acid as studied in the solid, in polar solutions, and on gold nanoparticles. J Phys Chem C 111: 3369-3383

18. Morelli B (1983) Spectrophotometric study of the ruthenium(III) - 2thiobarbituric acid system. Analyst 108:386-394

19. Godlewska-Żyłkiewicz B, Malejko J, Leśniewska B, Kojło A (2008) Assessment of immobilized yeast for the separation and determination of platinum in environmental samples by flow injection chemiluminescence and electrothermal atomic absorption spectrometry. Microchim Acta 163:327-334

20. Filatova DG, Shiryaeva OA, Zorov NB, Karpov YA (2006) Aqueous ammonia as matrix effect suppressor in determination of noble metals by electrothermal atomic absorption spectrometry: a novel approach. Anal Chim Acta 565:234-239

21. Lewis AE (2010) Review of metal sulphide precipitation. Hydrometallurgy 104:222-234

22. Chen Z, Foyer BJ, Longerich HP, Jackson SE (1996) Determination of the precious metals in milligram samples of sulfides and oxides using inductively coupled plasma mass spectrometry after ion exchange preconcentration. J Anal At Spectrom 11:805-809 